\title{
A giant beaver (Castoroides ohioensis Foster) fossil from New Brunswick, Canada
}

\author{
R.F. Miller ${ }^{1}$, C.R. Harington ${ }^{2}$ and R. Welch ${ }^{3}$ \\ ${ }^{I}$ Steinhammer Palaeontology Laboratory, New Brunswick Museum, Saint John, \\ New Brunswick E2K 1E5, Canada \\ ${ }^{2}$ Canadian Museum of Nature (Paleobiology), Ottawa, \\ Ontario K1P 6P4, Canada \\ ${ }^{3}$ St. Andrews, New Brunswick E5B 1C4, Canada
}

Date Received: April 12, 2000

Date Accepted: June 21, 2000

\begin{abstract}
An isolated incisor tooth of a giant beaver (Castoroides ohioensis Foster) recovered from Indian Island, New Brunswick, near the mouth of the Bay of Fundy, represents the most eastern record of this animal in Canada. Unfortunately no stratigraphic context is available for the specimen, which was recovered loose near a beach also known to yield archaeological materials. The specimen may have been deposited on a storm beach from near shore deposits, but it is also possible that the tooth was carried to the site by people. The rarity of giant beaver fossils in southern Canada adds to the significance of this specimen.
\end{abstract}

Une incisive isolée de castor géant (Castoroides ohioensis Foster) récupérée sur l'île Indian, au Nouveau-Brunswick, près de l'embouchure de la baie de Fundy, représente la trace physique la plus à l'est de la présence de cet animal au Canada. Malheureusement, on ne dispose d'aucun contexte stratigraphique dans le cas de ce spécimen, qui a été récupéré sous une forme détachée près d'une plage également reconnue comme source d'objets archéologiques. Le spécimen pourrait provenir de dépôts littoraux et avoir été déposé sur une crête de tempête, mais il est aussi possible que des gens aient apporté la dent sur les lieux. La rareté des fossiles de castor géant dans le Sud du Canada rehausse l'importance de ce spécimen.

Traduit par la rédaction

\section{INTRODUCTION}

Although fossils of giant beaver are widely distributed in Quaternary deposits across North America only two localities in Canada have yielded specimens of this large rodent. Fossils from Old Crow, Yukon (Harington 1977, 1978) and the Don Formation in Toronto (Coleman 1933; Harington 1978) are the only Canadian records for an animal that was distributed from Alaska [the only evidence is a small fragment of incisor tooth from Cripple Creek near Fairbanks collected in 1942 (Harington 1996)] and Yukon in the north to Florida in the south, and from Nebraska to New York State (Harington 1996). Thirty-four localities from Late Wisconsinan to late-glacial $(40,000$ to 10,000 years B.P.) have been recorded, most of the sites being south of the Great Lakes and near the east coast of the United States (FAUNMAP 1994; p. 509). In the Old Crow region, giant beaver fossils occur in deposits of the Sangamonian interglacial (about 130,000 to 75,000 years B.P.) (Harington 1977). The specimen from the Don Valley Brickyard deposits in Toronto is also thought to be from the Sangamonian interglacial.

Giant beavers were indeed giant compared to their modern relatives. They were the largest ice age rodents in North America, measuring up to $2.5 \mathrm{~m}$ long with an estimated weight of $200 \mathrm{~kg}$, compared to a $1-\mathrm{m}$ long modern beaver (Castor canadensis Kuhl) weighing about $30 \mathrm{~kg}$. Although some authors (Kurtén and Anderson 1980; Anderson 1984) consider its habits to have been more like a muskrat than a modern beaver, one must ask why Castoroides had cutting teeth up to $15 \mathrm{~cm}$-long with prominently-ridged outer surfaces. Perhaps these strong enamel ridges would have acted as girders to support such long teeth. Further, the deep masseteric fossa of the lower jaw suggests a very powerful bite. Perhaps their teeth could have acted as both wood-cutters and gouges. There is no clear evidence that the giant beaver felled trees or built dams, but a possible lodge was discovered near New Knoxville, Ohio about 1912. Part of a giant beaver skull and the lodge were located in a peaty layer surrounded by loam. The lodge was roughly $1.2 \mathrm{~m}$ high, $2.4 \mathrm{~m}$ in diameter, and formed from saplings about $7.5 \mathrm{~cm}$ in diameter (Williamson 1912).

This specimen documented herein represents the most eastern occurrence of giant beaver in North America, and a new locality for Canada. Unfortunately no stratigraphic context is available for the specimen, which was recovered loose near a beach also known to yield archaeological materials. It does not appear that the specimen was eroded from late-glacial deposits on the island; however, offshore occurrences of Quaternary mammals along. the eastern seaboard allow for the possibility that the specimen was derived locally. The specimen may have been tossed up from the seafloor during a storm. Indeed, its discovery on a gravel 
ridge separating the beach from a salt marsh suggests that it may have been washed up on an ancient storm beach. Caribou bones (NBM collections) and Pleistocene to Holocene walrus remains (Miller 1990, 1997) have been dredged from the Bay of Fundy, and Quaternary terrestrial mammals have been recovered from the continental shelf on the east coast of North America (Whitmore et al. 1967; Gallagher et al. 1989; Cooke et al. 1993). Still, the specimen could have been carried to the site by humans from elsewhere. Direct associations of early peoples and giant beaver are not known and this specimen shows no sign that it has been worked. The oldest archaeological materials from Indian Island probably date to the Woodland Period, about 2,500 to 500 years ago (D. Black, personal communication, 1999). Giant beaver died out about 10,000 years B.P. (Harington, 1996).

\section{LOCATION}

The specimen was found in 1998 on Indian Island (approx. $44^{\circ} 56{ }^{\prime} \mathrm{N}$; $66^{\circ} 58^{\prime} \mathrm{W}$ ) (Fig. 1), a small island ( $2 \mathrm{~km}$ long by $0.5 \mathrm{~km}$ wide) southeast of Deer Island near the mouth of the Bay of Fundy. The fossil was recovered on the southeast corner of the island, lying loose on a gravel ridge (berm) between the beach and a salt pond. The bedrock of the island is comprised entirely of Cambrian rocks of the Simpson Island Volcanics (McLeod et al. 1994) with only a thin veneer of Quaternary sediments (Rampton et al. 1984). Shallow waters surround the islands of the Deer Island-Campobello Island archipelago. Water depth around Indian Island is $9 \mathrm{~m}$, dropping to 34 and $65 \mathrm{~m}$ in the channels separating it from the other islands.

\section{DESCRIPTION}

\section{Order Rodentia \\ Family Castoridae \\ Castoroides ohioensis Foster, 1838}

Fig. 2a, b

The specimen (NBMG 10368) is a damaged upper right incisor tooth, having the following characters typical of such giant beaver incisors: (1) ribbed anterior and lateral surfaces; (2) large size (this tooth is very large suggesting highly favourable palaeohabitat in comparison to two other right upper incisors from Old Crow Basin, Yukon, Table 1); (3) flattish medial surface with a slight groove running the length of the tooth; (4) strongly curved tooth with a deep groove along the posterior surface, the deepest side being medial. Much of the lateral surface of the specimen is damaged and the outer enamel ribs appear to have been slightly eroded. The specimen is pale buff in colour with strong iron-staining at the proximal (root) end where the pulp cavity is exposed. The tip is slightly damaged.

\section{DISCUSSION}

The Quaternary terrestrial mammal fauna of New Brunswick is sparse, consisting of the Hillsborough Mastodon (Mammut americanum (Kerr)) and indirect evidence of beaver (cf. Castor canadensis) both of Sangamonian age (Harington et al. 1993), and two undated woodland caribou (Rangifer tarandus (Linnaeus)) antlers from offshore of Grand Manan Island. The Quaternary marine mammal record is better, with a number of recorded occurrences of walrus (Odobenus rosmarus (Linnaeus)), whales (Balaenoptera acutorostrata Lacépède, Delphinapterus leucas (Pallas), Monodon monoceras Linnaeus), and a seal (Phoca sp.) (Miller 1990; 1997; Dyke et al. 1999). The age of the giant beaver is unknown, but the American mastodon from Hillsborough, as well as a few mastodon fossils from Nova Scotia, is assigned to a cool phase of the Sangamon Interglacial, probably oxygen-isotope substage $5 \mathrm{a}$, prior to the Wisconsinan glaciation (Harington et al. 1993). The Milford mastodon from Nova Scotia has been dated by electron spin resonance (ESR) at approximately 74,500 years B.P. (Godfrey-Smith et al. 1997). In the Great Lakes region of North America the American mastodon is associated with browsers indicative of forested areas, including the giant beaver (King and Saunders 1989). Giant beaver may have been part of a similar Sangamon fauna in the Maritimes, as well as a member of the late-glacial mastodon/giant beaver/stag-moose (Cervalces scotti (Lydekker)) group that was not uncommon in eastern North America.

The discovery of giant beaver remains in New Brunswick adds significantly to the Quaternary terrestrial mammal fauna of New Brunswick and suggests that the terrestrial fauna was probably richer than earlier evidence indicated. The known North American distribution of giant beaver is not significantly changed by this occurrence. Although this fossil falls within the animal's suspected range, its discovery adds a third locality to the Canadian records. If evidence is ultimately found that this specimen was transported to the site by humans it would be equally interesting since little is known concerning human-giant beaver interaction.

\section{ACKNOWLEDGEMENTS}

We thank Robert Grantham (Nova Scotia Museum of Natural History) and Kevin Seymour (Royal Ontario Museum) for critical reviews of the manuscript. Kevin Seymour kindly provided measurements of ROM 3358 from the Don Valley Brickyard. Donald McAlpine (New Brunswick Museum) and David Black (University of New Brunswick) assisted with information during the preparation of this manuscript. The New Brunswick Museum wishes to thank Arlene and Ralph Welch for donation of the giant beaver tooth to the museum.

\section{REFERENCES}

ANDERSON, E. 1984. Who's who in the Pleistocene. A mammalian bestiary. In Quaternary Extinctions. Edited by P.S. Martin and R.G. Klein. University of Arizona Press, Tucson, pp. 40-89.

COLEMAN, A.P. 1933. The Pleistocene of the Toronto region (including the Toronto interglacial formation). Ontario Department of Mines Annual Report, 41, $55 \mathrm{p}$.

COOKE, H.B.S., HARINGTON, C.R., \& Sollows, J.D. 1993. Undescribed mammoth (Mammuthus) teeth from Georges Bank and Nova Scotia. Proceedings of the Nova Scotian Institute of Science, 40, pp. 19-28.

Dyke, A.S., HoOper, J., Harington, C.R., \& SAVelle, J.M. 1999. The late Wisconsinan and Holocene record of walrus (Odobenus 


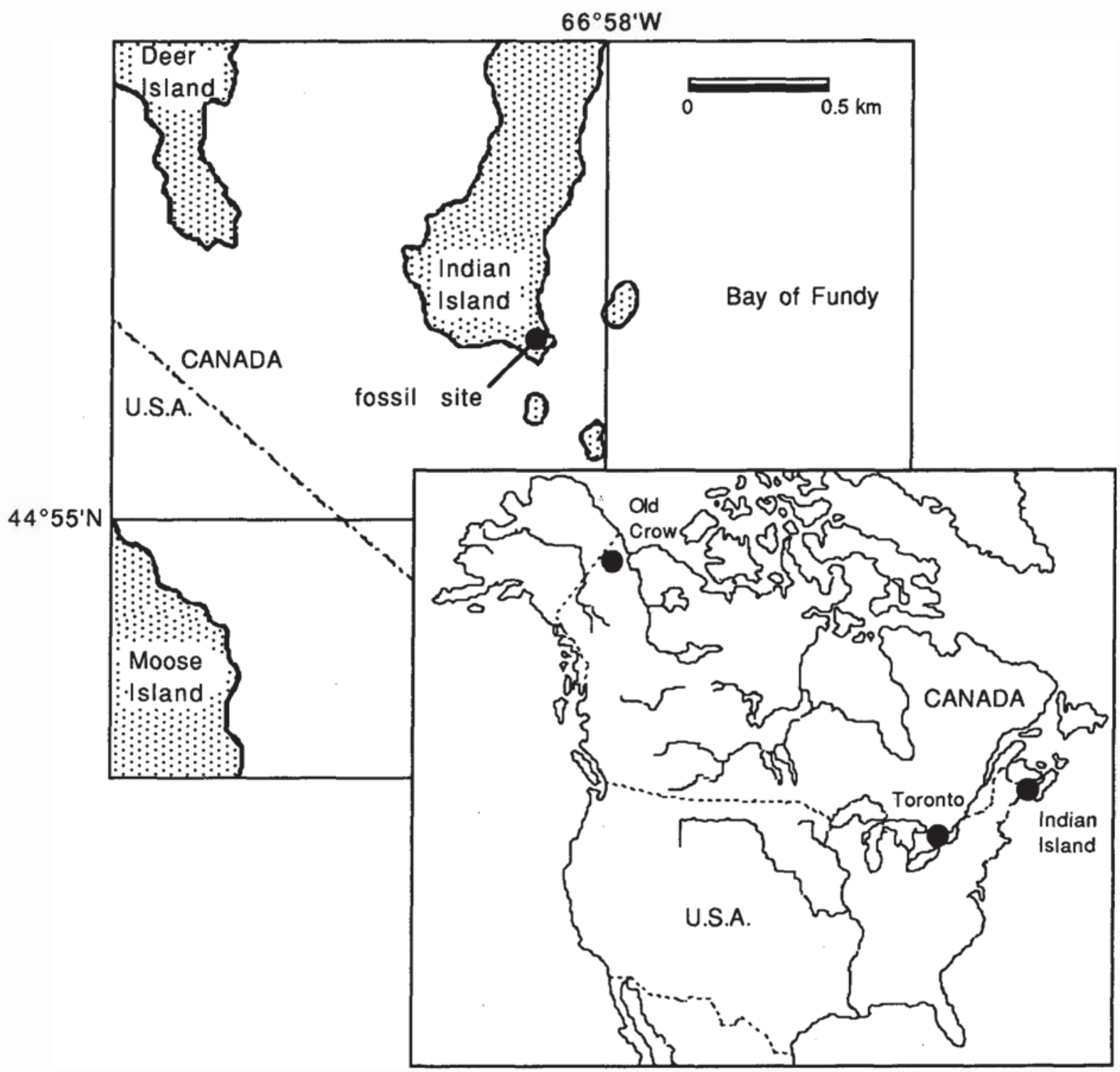

Fig. 1. Map of the Indian Island, New Brunswick giant beaver site, with an insert map of Canada showing the Canadian localities (1) Old Crow region, Yukon, (2) Toronto, Ontario (Don Beds), (3) Indian Island, New Brunswick.

Table 1. Comparative measurements of some giant beaver (Castoroides ohioensis) upper incisor teeth from Canada. All are right incisors except ROM 3358.

\begin{tabular}{lcccc}
\hline \multirow{2}{*}{ Specimens } & \multicolumn{4}{c}{ Measurements* } \\
\hline NBMG 10368; Indian Island, NB & 250.0 & 202.0 & 38.0 & 31.0 \\
CNM 51289; Old Crow Loc. 11A, YT & 225.0 & 178.0 & 26.0 & 25.0 \\
CNM 16056; Old Crow Loc. 44, YT & 175.0 & 130.0 & 22.0 & 21.5 \\
ROM 3358; Don Valley Brickyard, ON & 122.0 & 102.0 & 20.4 & 19.8 \\
\hline * 1 - Maximum length on anterior curve (as preserved); 2- Maximum length on posterior curve (as preserved); \\
3- Maximum width (mediolateral); 4 - Maximum depth (anteroposterior).
\end{tabular}


a)

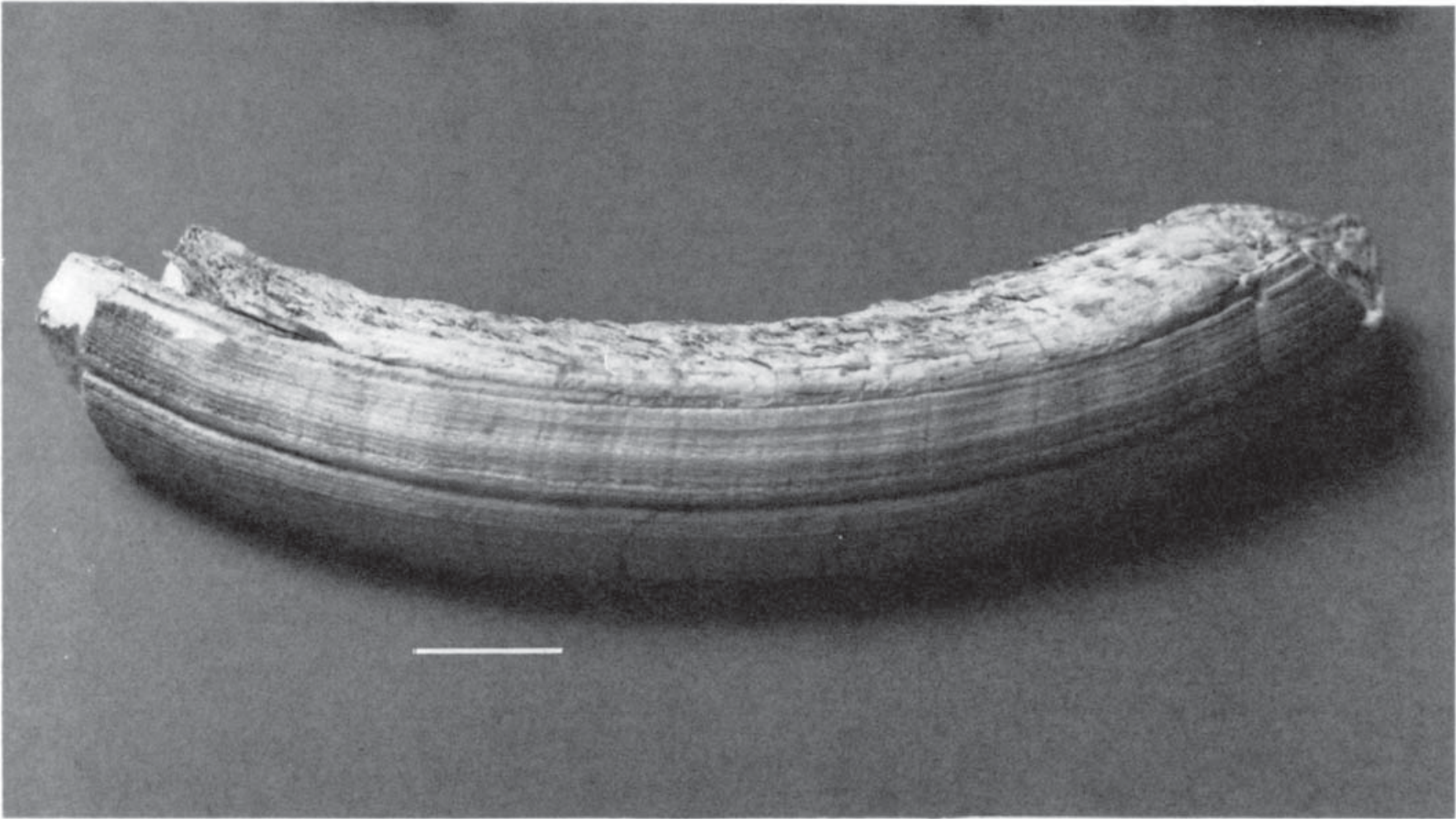

b)

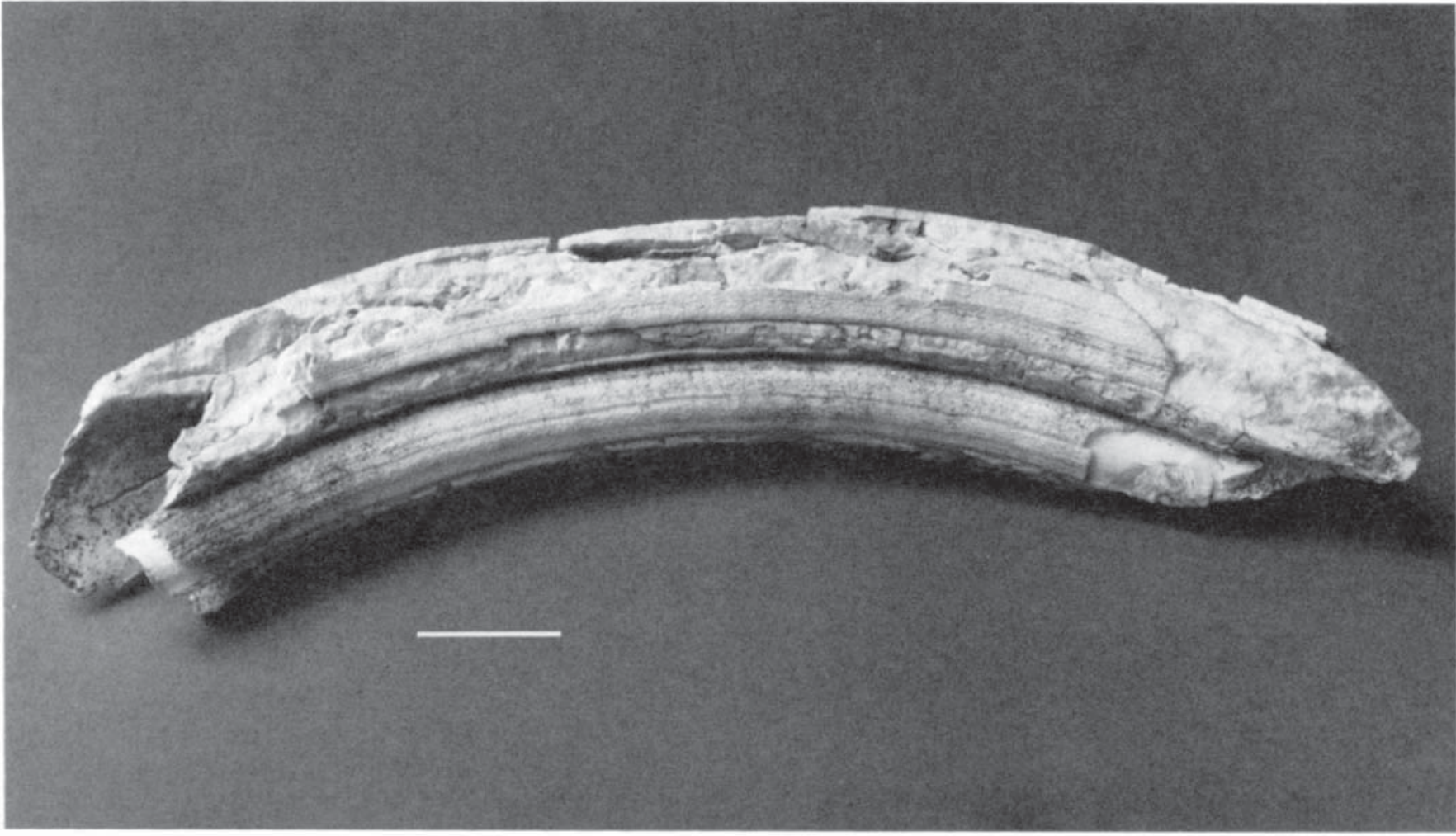

Fig. 2. Giant beaver (Castoroides ohioensis) right upper incisor tooth (NBMG 10368) from Indian Island, New Brunswick: a) oblique view showing the characteristic enamel ridges on the anterior surface (below) and the rather flat medial surface (above). Cutting end (tip) is to the right. Maximum length on anterior curve, $25 \mathrm{~cm} ;$ b) oblique view of NBMG 10368 showing the damaged lateral surface (above) and the characteristic deep groove in the posterior surface of the tooth (below). The slightly damaged cutting end (tip) is to the right and the broken proximal end (root) showing the pulp cavity is to the left. Maximum length on posterior curve, $20.2 \mathrm{~cm}$. Scale bar $=2 \mathrm{~cm}$. 
rosmarus) from North America: A review with new data from Arctic and Atlantic Canada. Arctic, 52, pp. 160-181.

FAUNMAP. 1994. FAUNMAP: a database documenting Late Quaternary distributions of mammal species in the United States. Illinois State Museum, Scientific Papers, 25(2), pp. 1690.

Gallager, W.B., Parris, D.C., GrandstafF, B.S., \& Detample, C. 1989. Quaternary mammals from the continental shelf off New Jersey. The Mosasaur, 4, pp. 101-110.

GODFREY-SMITH, D.I. GRIST, A., \& SCALLION, P. 1997. ESR and OSL geochronology of the East Milford, Nova Scotia, Canada, mastodon locality, and timing of the Illinoian-Sangamon transition. Atlantic Geology, 33, p. 61.

HARINGTON, C.R. 1977. Pleistocene mammals of the Yukon Territory. Ph.D. thesis, University of Alberta, Edmonton, 1060 p.

HARINGTON, C.R. 1978. Quaternary vertebrate faunas of Canada and Alaska and their suggested chronological sequence. Syllogeus, 15, pp. 1-105.

HARINGTON, C.R. 1996. Giant beaver. Beringian Research Notes, No. 6, pp. 1-4.

HARINGTON, C.R., GRANT, D.R., \& MOTT, R.J. 1993. The Hillsborough, New Brunswick, mastodon and comments on other Pleistocene mastodon fossils from Nova Scotia. Canadian Journal of Earth Sciences, 30, pp. 1242-1253.

KING, J.E., \& SAUNDERS, J.J. 1989. Environmental insularity and the extinction of the American mastodont. In Quaternary
Extinctions. Edited by P.S. Martin and R.G. Klein. University of Arizona Press, Tucson, pp. 315-339.

KURTÉN, B., \& ANDERSON, E. 1980. Pleistocene Mammals of North America. Columbia University Press, New York, 443 p.

MCLEOD, M.J., JOHNSON, S.C., \& RUITENBERG, A.A. 1994. Geological map of southwestern New Brunswick. New Brunswick Department of Natural Resources and Energy, Mineral Resources, Map NR-5.

MILLER, R.F. 1990. New records of postglacial walrus and a review of Quaternary marine mammals in New Brunswick. Atlantic Geology, 26, pp. 97-107.

MILLER, R.F. 1997. New records and AMS radiocarbon dates on Quaternary walrus (Odobenus rosmarus) from New Brunswick. Géographie physique et Quaternaire, 51, pp. 107-111.

Rampton, V.N., Gauthier, R.C., Thibault, J., \& Seaman, A.A 1984. Quaternary Geology of New Brunswick. Geological Survey Canada, Memoir 416, 77 p.

WhITMORE, F.C., JR., EMERY, K.O., COOKE, H.B.S., \& SWIFT, D.J.P. 1967. Elephant teeth from the Atlantic continental shelf. Science, 156, pp. 1477-1481.

Williamson, C.W. 1912. History of Ohio and Auglaize county. Geological Survey of Ohio Bulletin, 16, p. 39.

Editorial responsibility: Ron K. Pickerill 